\title{
توليد باميه
}
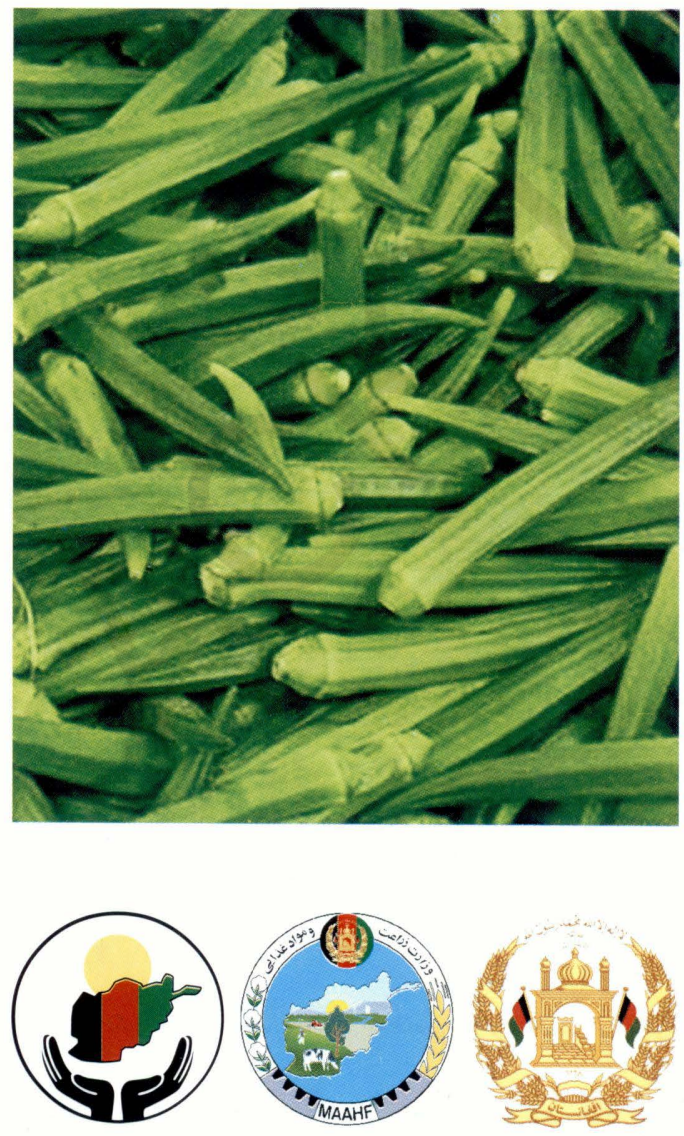

به جاى تخم حر ام، حلال كثت كنيد 
معلومات مختصر در مورد يرورش باميه

اهميت زراعتى باميه

باميه از جمله سبزيجات فصل تابستانى بشمار ميرود اكثر مناطق افغانستان براى كشت آن مساعد ميباشد. اهميت تجارتى باميه بسيار زياد ميباشد، زيرا بطور تازه و خشك مورد استفاده مردم

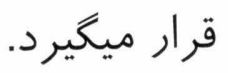

نيازمند يهاى اقليمى

باميه از جمله سبزيجات فصل كرم به شمار ميرود كه در هواى كرم خوب نشو نماى مينمايد. در مناطق كه فصل نشو نما آن كوتاه و شب هاى سرد دارد بطور خوب نشو نماى نميكند. در مناطق كه فصل نشو نما آن كوتا و شب هاى سرد دارد بايد

انواع قد كوتا و زود رس باميه كشت گردد.

جكونكى خاك

در صورتيكه اقليم خوب باشد، باميه در خاك هاى مختلف توانمندى توليد حاصلات قناعت بخش را دارد. براى حاصلات

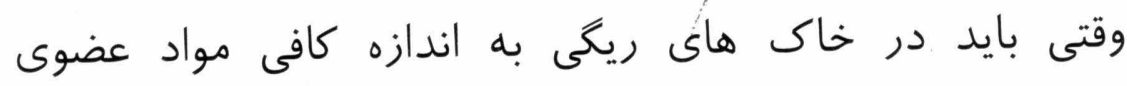
يوسيده شده انداخته شود، كار خوب است.

$1 / 6$ 
معلومات مختصر در مورد يرورش باميه

\section{وقت و طروق كشت}

در مناطق گرم تخم باميه در ماه حوت و در مناطق سرد در ماه ثور كشت ميشود. تخمم هاى باميه در rV - • درجه سانتى گراد زود و به شكل خوبتر سبز و جوانه ميزند. درصورتيكه حرارت از IV درجه سانتى گراد يايين باشد تخم هاى باميه جوانه نه زده و سبز نميخردد. تخم هاى باميه بسيار زياد سخت ميباشد و ييش از كشت بايد مدت FF ساعت در آب مرطوب نگهدارى شود. براى كشت تخم هاى باميه فاصله بين قطارها •.

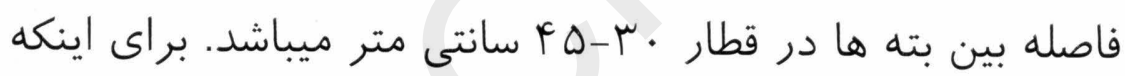
تخم بطور مطلوب توليد گردد، ضرور است كه از منابع موثق و با اعتماد بدست اورده شود.تخم بايد در خاك خوب وتر شده كه اندازه نم آن زياد باشد به عمق ץ سانتى متر كشت گردد. در

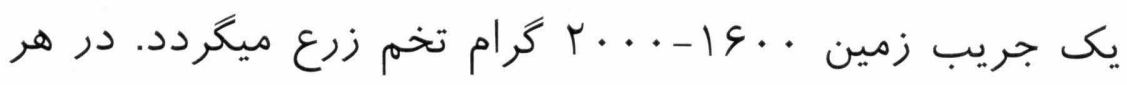
سوراخ بايد دو دانه تخم انداخته شود و بعد از جوانه زدن و سبز

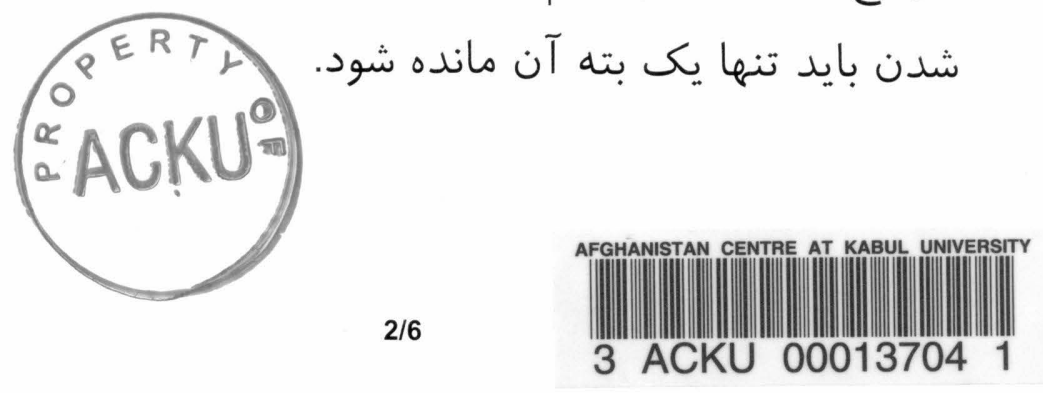


معلومات مختصر در مورد يرورش باميه

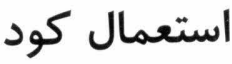

براى يرورش باميه در يك جريب زمين ه-ك تن كود حيوانى خوب يوسيده شده يا كميوست، ·ب كيلو گرام يوريا، ·ب كيلو گرام ترييل سوير فاسفيت و · r كيلو گرام يوتاشيم سلفيت مقدار خوب ميباشد. تمام كود حيوانى و نيم يوريا تمام، سوير فاسفيت و نيم بوتاشيم سلفيت در وقت قلبه كردن انداخته ميشود و مقدار باقى مانده يوريا و يوتاشيم سلفيت به اندازه مساوى بعد از كشت

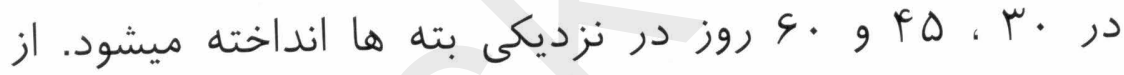
استعمال نايتروجن زياد خود دارى نماييد زيرا نشو نما بته ها را زياد نموده و سبب به تعويق انداختن حاصلات ميخردد.

آبيارى

اين سبزيجات در هواى گرم به آبيارى كافى ضرورت دارد، در صورتيكه هوا گرم و خشك باشد بايد آبيارى به وقفه هاى كوتاه صورت گيرد.

كنترول كياه هاى هرزه: جون جمع آورى حاصلات باميه از مزارع به وقت طولانى - 
معلومات مختصر در مورد يرورش باميه

ضرورت دارد. بنابر ضرورت ديده ميشود كه گياه هاى هرزه در تمام طول فصل نشو نما كنترول گردد. گياه هاى هرزه بايد توسط دست،رمبه و ملج سياه يلاستيكى تحت كنترول گرفته شود.

\section{جمع آورى حاصلات}

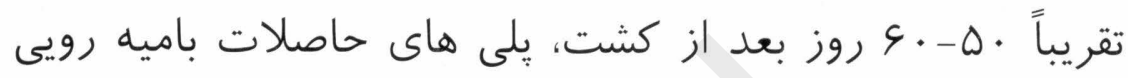

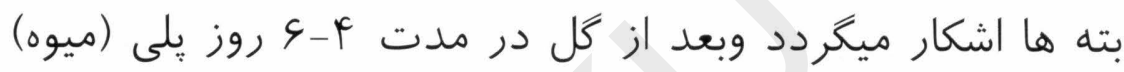
باميه به جمع آورى اماده ميگردد. باميه بايد بيش از يخته شدن در بته ها جمع آورى كردد و خوب خواهد بود كه حاصلات روزمره جمع آورى گردد. پيلى باميه بايد توسط جاقو يا قيجى قطع و جمع آورى گردد تا از زخمى شدن بته ها جلوگيرى شود. در صورتيكه ميوه جات باميه در بته ها زياد تخته گردد ريشه ها (فايبر) تشكيل ميگردد وبراى خوراك قابل استفاده نميباشد. تعداد زيادى امراض و حشرات بته هاى باميه را تحت حمله خود قرار ميدهد و سبب كاهش حاصلات و كيفيت آن ميخردد. بهتر خواهد بود كه در زمينه كنترول آن با مامور ترويج و يا اعضاء 


\section{معلومات مختصر در مورد يرورش باميه}

مسلكى اداره زراعت منطقه مشوره نماييد. خلاصه كنترول تعداد زيادى از اين آفات مهم قرار ذيل است.

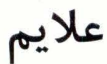

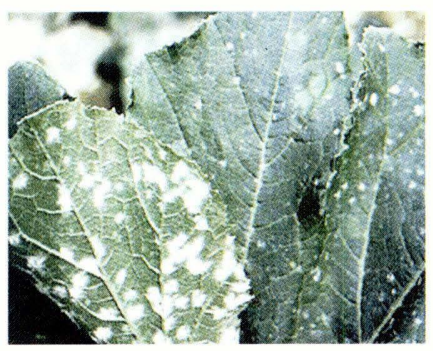

خاكستر
رويى برى هاى نبات گرد تشكيل ميكردد. برى ها خشى ميشود و وبا باس

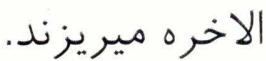
تداوى و جلوكيرى ليتر آب حل نموده و رويى بته ها پاش نماييد. علايم

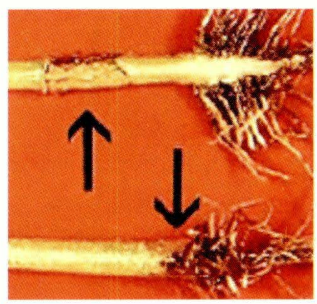

جِه شدن و مردن بته ها بعد از جوانه

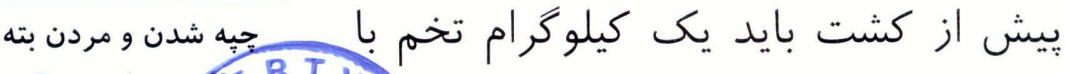
Damping off $R T$ T

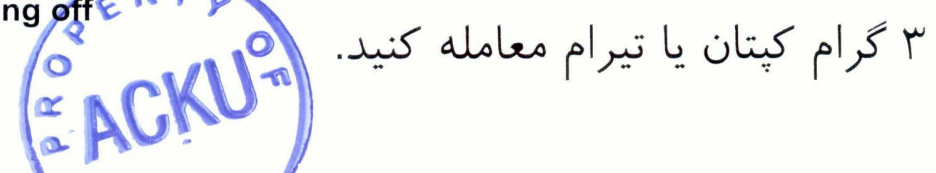


معلومات مختصر در مورد يرورش باميه

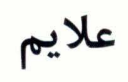

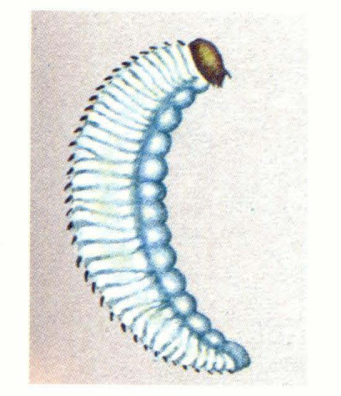

اين حشره تنه هاى بته باميه را تحت حمله

قرار ميدهد و آنها را سوراخ نموده و سبب

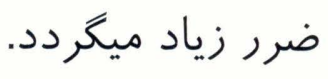

حشره سوراخ كننده شاخه ها

Shoot borer

\section{تداوى و جلو گيرى}

• استعمال لورسبان

• استعمال تايودان

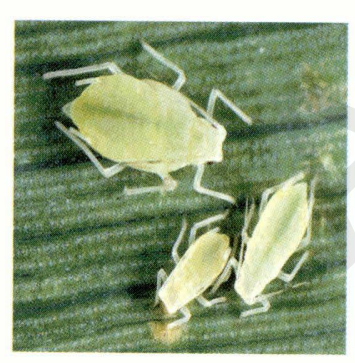

شيشك هاى نباتى

Aphids
علايم

روى برى ها و تنه هاى بته ها جاى كرفته و از شيره آنها تغذيه ميكند.

تداوى و جلو گيرى

دوإياشى لورسبان 
ACKU
$B 3$
5.142
$M 0 A$
13804

cop-1
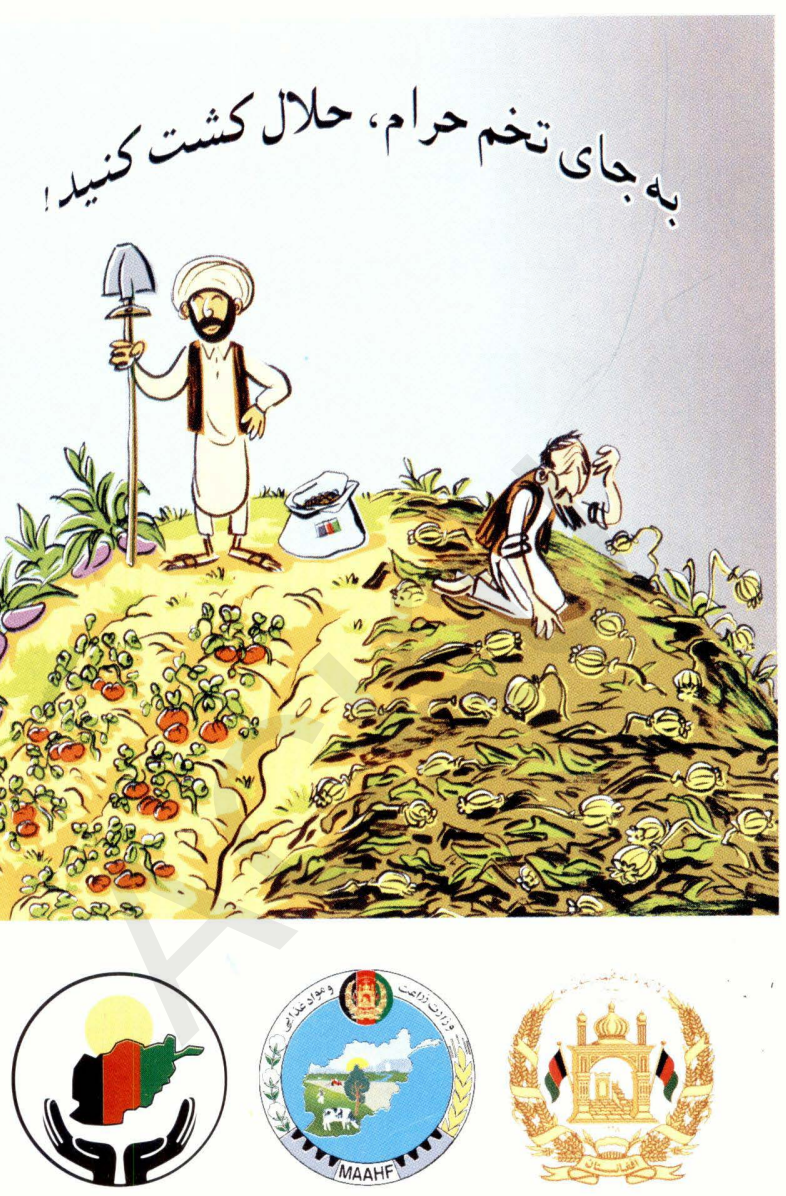

وزارتهاى زراعت و مبارزه عليه مواد مخدر با هم يكجا كار ميكنند تا كمكى براى دهاقين دينى كه

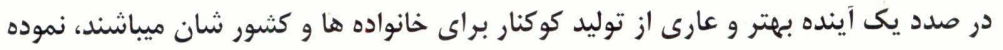

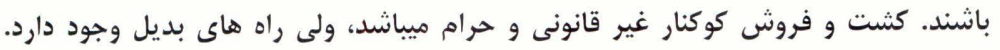

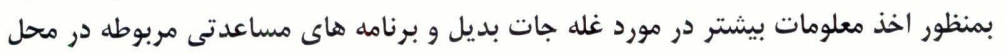

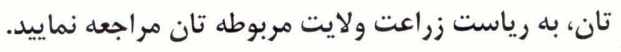

تحت نظر رياست نشر/ت وزارت زراعت، مالدارى و مواد غذاييى 